\title{
Sauvons Calais, a Nationalist Vigilante Group
}

\author{
Matthijs Gardenier
}

University Paul Valéry, France

Copyright $@ 2018$ by authors, all rights reserved. Authors agree that this article remains permanently open access under the terms of the Creative Commons Attribution License 4.0 International License

\begin{abstract}
This article focuses on a French anti-refugee vigilante group: Sauvons Calais. Linked to the radical far-right, it aims to mobilize the population against the presence of migrants in Calais. The goals of this nationalist group are the establishment of self-defense groups against refugees and the expulsion of all migrants. Its activities also take the form of vigilantism: calls for self-justice, patrols, direct action. We will also dwell on the cloudy links between the group and law enforcement agencies. Studying the emergence of this type of collective group is particularly interesting: given the situation in Europe, it is likely that these types of groups will start multiplying across the continent.
\end{abstract}

Keywords Refugee Crisis, Calais, Vigilantism, Borders, Far Right Activism, Nationalism

\section{Introduction}

This paper aims to examine the consequences of the refugee crisis in what has become a "hot spot", with a lot of tensions around this issue: the city of Calais and its surroundings, and its impact on nationalist groups. Since the Touquet agreements of 2003, signed between France and the United Kingdom, border controls are no longer on British soil, but in France, at the entrance of the port of Calais and in Coquelles on the Eurotunnel site.

This change generated a situation where many refugees that cannot go through to Britain remain in Calais for months or even years in order to attempt the passage. Without other means of support than what the NGOs can give, they live in informal settlements, called "jungles" or in squats, in very difficult conditions. Furthermore, it is important to know that most of these exiles are in a legal gray area. Many do not have a residence permit in order, which would allow them access to the labor market or to be supported as asylum seekers. However, they are not deportable either as they come from countries at war or that have not signed deportation agreements with the French authorities: Iraq, Syria, Afghanistan, Sudan, Somalia, and Eritrea.

Since the Arab revolutions of 2011 and even more since the "refugee crisis" of 2015, the number of migrants has risen sharply. In this paper, we will look into some political reactions to this situation, marked by very strong tensions.

To be more precise, we will look particularly into the phenomena of vigilantism against migrants. Vigilantism is the phenomenon in which "citizens" take charge of their safety or even justice themselves, without going through institutions such as the police and judiciary courts, outside of legality, considering the action of the security forces as inadequate[1].

This paper focuses on the development of an extreme right vigilantism against migrants. Several groups call for action against the refugees. We will focus in this paper on the "Sauvons Calais" group, which aims to defend Calais against what they call the "migratory invasion". It repeatedly calls for direct action against migrants, organizing demonstrations, sit-ins, and patrols. At the same time attacks on far-left activists and migrants multiply, even though they cannot be formally linked to the collective.

For us, the development of this type of group is a good example of what can happen around borders in a context of exacerbated tensions and economic crisis, as populism is developing. This article aims to document finely and in an ethnographic way its creation, its actions and its interactions with the population of Calais.

\section{Calais, a «Hot Spot» for Refugees}

\subsection{The Situation of the Refugees}

The first episode of the series of events that led to the situation as we know today in Calais began in 2002 with the highly publicized closure of the migrant shelter in Sangatte by Nicolas Sarkozy, then Minister of Interior. It welcomed several hundred refugees. Following this event, the Treaty of Le Touquet was negotiated between France and Britain. It was signed and ratified in 2003.One of its main measures is the removal of border controls at the entry of Britain; putting them into French territory instead (we have to remember that Britain is not part of the Schengen area). It is therefore situated at the entrance of the port of Calais and of the Eurotunnel in Coquelles, a few kilometers from Calais. This 
change was responsible to a great extent for the current situation at the border[2]. The border has since been reinforced by many safety devices, making the passage much more difficult for migrants. In consequence, refugees are increasingly stuck on the French side, creating a population in "storage "[3]. In addition, refugees have no means of subsistence, struggling to dress or to feed, living only through the help of NGOs. The refugees in Calais are in a very particular situation. The vast majority of them comes from countries at war or where there is no deportation agreement with the French government : Syria, Irak, Afghanistan, Erythrea, Sudan... On the other hand, they are not willing to apply for asylum in France, as they wish to do so in Great Britain. Thus they are in legal limbo, not in the asylum system, but also non-deportable by the border police.

There is also strong pressure on migrants: law enforcement agencies regularly evacuate squats and jungles. There is also a use of OQTF[4] as dilatory means: even if migrants are not legally eligible for deportation, they are often sent to detention centers in various places in France and then released after 40 days as the OQTFs are not executable and the refugees are not deported. This process aims to discourage migrants and especially to reduce temporarily the mass of people present around Calais. Its practical effectiveness is very limited because the refugees come back very quickly [5].

After several years of systematic expulsion from jungles and squats by the French police, since April 2015, migrants are concentrated in the "jungle" located around the Jules Ferry official camp. That camp was only a day care center with showers and toilets when it opened. In autumn 2015, it then became a "temporary reception camp", hosting 1500 places. In March 2016, the migrants from the southern part of the jungle were expelled by the police after days of protests and riots [6]. In July 2016, the Jules Ferry jungle still hosts between 3500 refugees according to the prefecture and 7000 according to the NGOs [7].

\subsection{A Very Complex Political Game in the Locality}

This situation is not without creating strong reactions in the population of Calais. Rather than a massive rejection of migrants, we observe a polarization of the population between two rival camps. From a humanistic perspective, some welcome and support the migrants. On the other side, a reaction of fear and rejection develops against migrants. These two different attitudes are quite intense and can lead to confrontations, as we shall see in the case of the Coulogne squat.

Around this situation a very complex political game has developed. Its stake is the management of the refugee situation. We can distinguish five main types of political actors. Moreover, given the global instability, the influx of migrants, but also the multiplicity of actors, most interactions are complex and their results unpredictable if not chaotic.
1. The first and most important actor is the French state. Under the direction of the Prefecture of Pas-de-Calais, a very large police force of around 1,000 officers is permanently stationed in Calais and its surroundings. It consists of riot police, interior intelligence (DGSI), custom officers and anti-gang squads. Under the direction of the prefecture, it monitors the vicinity of borders to prevent the passage of migrants to the UK. It also manages the temporary camps and squats, and often conducts the expulsion of the jungles. The police have sometimes had very violent interactions with migrants and No Border activists. Riots are frequent and many NGOs have blamed security forces for repeated and unjustified violence [8]. Moreover, we can note that the action of the state has two limitations that make its action difficult to read. According to the Touquet agreements, the French state has an obligation to block the passage of refugees to Britain. On the other hand, it is not legally possible to expel those refugees. This double bind generates automatically a situation where many migrants are stranded in Calais. The role of the state is largely to keep the situation status quo and then to manage its consequences.

2. Local officials: they are mainly represented by the team of Natacha Bouchart, Mayor of Calais (LR, conservative). They have a fairly low margin of action regarding the management of migrants. Nevertheless, the mayor of Calais has a big media impact. It is her call to the denunciation of refugee squats that led to the creation of Sauvons Calais.

3. Humanitarian NGOs: Those associations such as Salam, MSF, Solid'R, La vie active, only to name the biggest, act in order to provide an immediate assistance to the migrants, with tents, clothes, shoes but also meals. Overall, their contribution is essential to the survival of migrants, but remains insufficient to ensure decent living conditions.

Beyond humanitarian assistance, these associations sometimes maintain an ambiguous attitude towards refugees. Indeed, this aid is financed through grants from the state, local authorities (county, region) and Europe. These associations also compete to gain "market share" in migrant management, as every subsidy means more work within the NGO's. Mathilde Pette speaks of "the certificative pole" to describe these associations, which have a humanistic approach. They will help the refugees, but without questioning the migratory policies at the root of the Calais situation. It opposes the "revendicative pole" which, in contrast, adopts a position of protest [9].

4. The movement of support to the refugees. It is distinct from the humanitarian associations. It places itself in a perspective of collective struggle and aims to encourage the self-organization of migrants. Its aim is to help refugees on a daily base and to assist the passage through the border by organizing collective actions. It has several components: The No Border activists that are present in the jungles, in connection with the association Calais Migrants Solidarity. There is also the anti-fascist movement, and various associations, such as La Goupille or Calais Ouverture et humanité. 
5. Various anti-migrant movements. They are opposed to the presence of migrants. The FN [10] is not involved and does not position itself strongly in relation to these issues despite good electoral results in the region. The main actors of this trend are "citizens" anti-migrant groups. They claim to be apolitical, but are directed covertly by the radical far right. The two major groups are Sauvons Calais and Calaisiens en colère. In this paper, we will focus on Sauvons Calais.

\section{Sauvons Calais, between a Social Movement and a Vigilante Group}

\subsection{Field Research}

October 23, 2013, on her personal Facebook page, the mayor of Calais, Natacha Bouchart (LR) published a call prompting Calaisiens to denounce any implementation of squats populated by migrants, to facilitate the activities of law enforcement agencies.

This call was publicized nationally and created a great controversy, as some accused it of stirring up hatred. Following that controversy, the Facebook page Sauvons Calais [11] was created, and a few weeks later the collective of the same name was formally created. From the beginning, its goal has been to mobilize the locals against migrants, listing squats, responding in some way to the call of the mayor of Calais, but also inciting to act against migrants to "Save Calais ".

This group, composed of a core of about twenty activists that can gather up to hundreds of people in anti-migrant demonstrations. Early in our field research, we made the assumption that Sauvons Calais was a pure fascist militia. After a stint in the field, with a series of interviews, but direct observations of their actions, it rather seems that Sauvons Calais is a collective whose character is hybrid, between the social movement and the militia.

The two trends came together in an episode on which we will focus: the mobilization against the Coulogne squat in February 2014.

We went several times to Calais in the spring of 2015, in March and June. We opted for a qualitative methodology, permitting detailed analysis, in an ethnographic way, in order to analyze in detail the motivations, words and actions of the actors we met.

The backbone of our investigation is fifteen interviews with various actors, between $20 \mathrm{mn}$ and 1:30, depending on the availability and the propensity to speak of people we met.

It is complemented by a thematic analysis of the contents published on the Facebook page of Sauvons Calais over a two month period, as well as direct observation of the group's press conference on 7 June 2015. These additional elements allow us to better understand the political communication of Sauvons Calais.

The survey is part of a larger project on the emergence of vigilantism in France. Interviews are recorded when people wish to remain anonymous. If the interviewees accept, they are filmed. It should also be noted that interviews are sometimes made in difficult conditions. Some people, including refugees, are reluctant to talk to us, as they fear reprisals.

Thus, we distinguish five "groups" of profiles that correspond more or less to the list of actors detailed above. For instance, we encountered difficulties to interview members of Sauvons Calais, which are quite suspicious of people they don't know personally. At first, Kevin Rêche, leader of the group, did not wish to meet with us and our email contact requests remained unanswered. Then several appointments that we could make with some of the group's activists were canceled at the last minute. In the end, we managed to get a long interview with Michael Paepe, senior member of the group, and local leader of the Parti de la France [12]. He is older and more politically mature than the rest of the activists. We also have interviewed Samuel Delcloy, an activist close to the Identitaires [13], which participates in Sauvons Calais actions while trying to organize a competing collective, which will in the end become the Calaisiens en colère.

We easily get more interviews with locals who are not activists, but who have participated to Sauvons Calais actions. We meet a neighboring resident of the Jules Ferry jungle, a resident of Coulogne who participated in the siege of the squat and a local with a specific profile, Katie. At first, she engages in the mobilization against the Coulogne squat organized by Sauvons Calais before switching sides and joining the No Border activists. Associative and pro-refugee activists are willing to meet with us and be recorded, with the exception of No Border activists that accept informal talks, but refuse that we take notes or record any of their words. We also conduct interviews with Marie Hélène Calonne, solicitor of the No Border activists and with "Gros Marian", antifascist activist, who is regularly in confrontation with the militants of Sauvons Calais on the streets. We also met with Nelle, activist of the association Calais Ouverture et humanité who tells us about her aggression by far-right activists. We also met Philippe Wannesson activist and host of the blog "Passeurs d'hospitalités"

Local elected officials also gave us interviews. We met the Mayor of Coulogne (Alain Fauquet, Socialist Party, center left), and Emmanuel Agius, first deputy mayor of Calais (Les Republicains, conservative). We also met two migrants, Abdul and Hassan, victim of assaults by far-right activists. These interviews were difficult to conduct because of the language barrier and the context, as they were made in the middle of a jungle.

The state prefecture did not respond to our requests for interviews. To conclude, we will say that our field research was guided by two perspectives. The first was to make a sociography of the group in order to better understand its action but also its ideology. The second was to consider it through the particular perspective of vigilantism as a form of 
activism, but also of political violence. We favored this approach initially. We quickly realized that the nature of this group was more complex, mixing vigilantism and social movement features to satisfy an objective: the imprisonment and deportation of refugees all throughout the Calais region.

Let us recall that vigilantism lies not only violent in action, but also in the implementation of its threat and the ways it is publicized. This provides it with a social existence and visibility that goes far beyond simple acts of coercion. This dimension applies very well to the calls for self-justice posted on the Facebook page of Sauvons Calais [14].

\subsection{Ideology and Claims of the Group}

In order to have a better idea of the physiognomy of the collective, we will start by studying its ideology and its claims. We will begin with elements collected on the internet site of Sauvons Calais, the interview conducted with Michael Paepe, but mostly with the press conference of June 7, 2015 we attended. It is organized instead of a demonstration that has been banned by the prefecture. The activists giving speeches are Kevin Rêche, leader of Sauvons Calais, Thomas Joly, regional leader of the Parti de la France and Yvan Benedetti, leader of l'Eeuvre Française [15].

First, the group manifests a particular representation of refugees. In imaginary terms, they embody the figure of the enemy. Terms such as "invasion" and "colonization" are used very regularly in the speeches to label them. The situation in Calais is described as an "abscess". Yvan Benedetti speaks of migratory submersion, which would lead to an apocalyptic future not only for the city, but for the whole of France.

According to them, the government does not allow the police to do its job, which would explain the situation. There would be a lack of political will from the state which would justify vigilantism. Examples given repeatedly are the regular assault of truckers by refugees trying to board their trucks.

According to Rosembaum and Sederberg "the potential for vigilantism varies positively with the intensity and scope of belief that a regime is ineffective in dealing with challenges to the prevailing sociopolitical order" [16].

The discourse of the collective is clearly staging such beliefs. It would be the lack of political will of the state that would be the basis of the problem. To remedy this, Sauvons Calais has a program centered around three revendicative axes.

\subsection{The claims of Sauvons Calais}

1. The first claim would be the establishment of popular militias based on the Neighborhood Watch system, but with extended powers, to control and repress the refugees. When Yvan Benedetti speaks of this project he refers to vigilante groups in Italy and Hungary. In these countries, referring to the radical far right militias of the Hungarian Guard and the
Lega Norde [17], he considers that "They are exasperated people who take their defense into their own hands." He continues "It's very simple: they are there to coordinate the action and to monitor the streets." He adds the idea that the supervision of authorities remain necessary and that they would not be equipped with firearms.

2. The group's second axis is a call for the dissolution of "migrationnistes" groups supposed to act "as slavers" and to bring migrants to the slaughterhouse, for the benefit of "international finance and oligarchy". The claim of the group is the "dissolution of all NGOs" that help one way or another refugees and especially the No Border group, called "the worst enemy of the French people". This part of the program is phrased as a claim addressed to the State, but they do not exclude a more immediate use of vigilantism to counter groups supporting refugees, as we will see when discussing the siege of the Coulogne squat.

3. The third axis (which is far more developed than the other two) is a call for the closure of borders and a total shutdown of extra-European immigration. According to Yvan Benedetti, "when the plate is empty, it is not a good idea to bring in extra mouths especially if they are foreign to share the little we have left." Furthermore, this closure would be made on humanitarian grounds, to prevent human trafficking.

On the longer term, the perspective would be to organize the "re-migration" of non-European populations: in order to "protect the French." According to Yvan Benedetti, this mass deportation would avoid suffering to the "uprooted" migrants but also to the "indigenous populations". He also proposes to cut social benefits for foreigners because it "creates an artificial aid" and would contribute to the launching of "an immigration pump."

Finally, according to Benedetti, it would not be necessary to accommodate refugees or asylum seekers. For him, refugees are cowards: if a situation were to become intolerable in a country at war, migrants should stay to fight against oppression. Questioning the concept of a political refugee, he says "These men have no courage, what do they have between their legs?".

Concerning the situation in Calais, these claims materialize in a specific project: lock up all migrants in a closed camp. In the interview he granted us, Michael Paepe said that there should be no difference between undocumented migrants and legal asylum seekers in order to avoid "generating confusion." Moreover, for Sauvons Calais activists, self-defense committees should support government forces to implement the camp, not hesitating to denounce and arrest the migrants in order to lock them up. Given this set of claims, it seems that Sauvons Calais is a group with fairly consistent goals: the imprisonment and deportation of all migrants of the Calais region. In order to do this popular mobilization and especially vigilantism are the tools that its members plan to use in order to achieve their goals. We will now discuss a concrete action of the group: the siege of the Coulogne squat which seems rather 
emblematic of Sauvons Calais methods of action.

\subsection{The Siege of the Coulogne Squat}

According to the newspaper La Voix du Nord, No border activists squatted on a farm on rue Emile Dumont in Coulogne, near Calais on 2nd February 2014. It was opened in support of refugees. Sauvons Calais then organized a sit-in with locals of Coulogne to seek eviction of the squat. The sit-in was attended day and night. It quickly turned into a siege that lasted fifteen days, until the 17th of February, with the active participation of the population of Coulogne, and without any police intervention. It ended with stone throwing's on the house that made the farm uninhabitable. The stoning, conducted by the demonstrators went on for eight days. The farm was then destroyed by fire once the squatters left the premises.

To go further than what we could see in the newspapers, we went there and we met the protagonists of the events. We spoke with the mayor of the village, with local residents who attended the mobilization, with Sauvons Calais activists and on the other side with the No Border activists. In psychological terms, we note discomfort when we talk to all the participants of this mobilization. They have difficulty recognizing their contribution and even more to take responsibility, each one blaming someone else for the violence that led to the destruction of the squat.

According to a local resident who participated: "People of Coulogne did not want it taking more scope". He does not want to mention the events. "There was in fact no brutality, no violence". Then he explains to us that people threw stones on the roof tiles of the farm for eight days. "There was no brutality." "It was very well planned". For us, it is an example of a total minimization of the violent actions that took place.

The Mayor of Coulogne tells us that the council has handled the issue on a legal basis. According to him it is Sauvons Calais that organized the demonstrations and said it was responsible for the mobilization. The group is the cause of violence. According to him, they went to fill "large stone bags on the railway to organize the stoning." The mayor makes a difference between people of Coulogne who have not participated in the violence according to him and Sauvons Calais who allegedly imported the virus of violence. We can note that the testimony of the neighbor and of Katie somehow contradict the mayor.

According to Michael Paepe, member of Sauvons Calais and local leader of the Parti de la France, on the contrary there was no violence. Accusations that Sauvons Calais would be violent originate in the "pro-immigration lobby and specifically the No-border activists". He denies any violent action claiming that Sauvons Calais is a respectable group in line with social movements and that violence is absolutely not part of its mode of action. According to him, the various attacks are the work of people he does not know. "There is no evidence that members of the group are involved in the violence", he adds "we cannot take responsibility for all individual acts by disturbed people." Similarly, these accusations would be an act of "defamation arising from migrationnistes groups."

We have a different version when we talk to the activists. According to the No Border we meet, the Sauvons Calais activists have engaged in numerous degradations, and stone throwing. According to Katie, rumors circulated that "the occupied farm would host a hundred migrants". Sauvons Calais then organized a demonstration outside. She participates, as do most neighbors.

She said, "I went there twice, I participated". Then she went to talk to the No Border. They told her that there were only ten migrants that were coming and not a hundred as claimed by the activists of Sauvons Calais. When she returned to tell that to the demonstrators, she was rejected by activists of Sauvons Calais. At this time, that was a tipping point for her. She joined the pro-refugee activists. She told she heard screams such "gas chambers", and that there were break-in attempts by militants of Sauvons Calais.

She said, "What worries me most is that it was a general madness, there were parents and their children throwing stones. Sauvons Calais, they are not stupid, they did not throw stones in public, they went to see groups, encouraged them and gave the stones. It is at night when locals left that the militants of Sauvons Calais threw stones" She said she was traumatized by the events.

The story of Philippe Wannesson intersects with the one told by Katie and the No Border activists. He builds a more analytical discourse, posing both as a player and a commentator. The main addition of his intervention concerns the role of the police. Despite Molotov cocktails being thrown, despite the stoning, officers are only present during the day. During the night when there is the most serious violence, the police is not present. The No Border organized group calls to the police, but there was no intervention. According to Philippe Wannesson "What I learned that day is that you can stone the roof of your neighbors. According to the prefecture, it is not a disturbance of public order".

In this action, we can witness a mix between vigilantism and social movement. It starts with the mobilization of the neighborhood against the squat and by organizing daily demonstrations. Secondly, vigilantism takes over. Thus, the stone throwing opens the way. The stoning is organized by Sauvons Calais activists who do not compromise themselves in public. They only commit violence at night, when the police are not present, and after the residents have returned home: death threats, break-ins, stone throwing, but also Molotov cocktails. Similarly, it is at night that the squat is burnt once the occupants have left it.

\section{Analysis of the Action of the Group}

\subsection{Between Right-Wing Social Movement and Vigilantism}

After having presented concrete elements of the ideology 
and actions of the group we gathered on the field, in this part, we will try to analyze the different actions of the group, but also to explore its complex relationship with the government.

Early in our field research, we made the assumption that Sauvons Calais was a fascist movement and purely a militia. After our research, it rather seems that it is a collective whose character is hybrid, at the crossroads between social movement and militia.

Its objective is the establishment of a camp for migrants, including those with papers (asylum seekers) and those who are not deportable. Its structure counts fifteen to twenty young activists of the extreme right, many of which feature a "skinhead" look. The group is structured around Kevin Rêche, aged 21.

Its actions are held on three fronts:

1. The first is the social movement front. The goal is to mobilize the population against migrants. Here is a list of actions undertaken by the group:

- Setting up a Facebook page denouncing migrants. Very popular, it spreads "information" about the situation and calls for mobilization. It counts 200,00 likes (people following the page). It has been accused of promoting racial hatred: there are many calls for diverse hate crimes posted on the page.

- Organization of petitions against refugee squats.

- Organization of events giving visibility to the claims of Sauvons Calais: for example the demonstration of 7 September 2014, with many French far-right groups (PTO, Identity Network, Young Nation).

- Mobilization against the squat in Coulogne: Organization of a "sit-in" with the inhabitants of Coulogne (suburban Calais) to push out the squatters. It merges with vigilante activity. 2. The second set of actions concerns vigilantism: A series of activities of Sauvons Calais intersects the activities of more traditional militias, "security assignments ", but also attacking social movements related to refugees. Here is a list of vigilante actions:

- Calls for the denunciation of squats on the Facebook page.

- Organization of patrols by Sauvons Calais activists against "migrant insecurity"

- Series of attacks against migrants and far-left activists: beatings, threats, insults, attempt of abduction, attacks on bars where activists gather. It should be noted that they are most of the time against isolated or vulnerable persons. They are characterized by their systematic and targeted nature, particularly against the association Calais Opening and Humanity. If there is no provable link between Sauvons Calais and this series of attacks, there are strong suspicions on the older supporters of the group. There are almost no responses from the police and judicial institutions concerning these attacks.
- $\quad$ Call to "self- justice", often followed by action: Among the anti-migrants attacks committed by isolated inhabitants of Calais, there is evidence that some were present at the $7^{\text {th }}$ September demonstration, and they were following the Sauvons Calais page where they posted before attacking the Egyptian squat with Molotov cocktails

- Organization of the attack on the squat in Coulogne with locals. 3. The third mode of intervention of Sauvons Calais is surprising: it takes part in the local electoral competition. Members of the group have made a candidacy to the county election of March 2015 in Calais. Its candidates are Michael Paepe and Kevin Rêche under the banner of the Parti de la France, whose national slogan is "Neither mosques or Islamic veil". The link between the collective Sauvons Calais and the electoral candidacy is clear: Kevin Rêche is at the top of the list and the campaign slogan is "Sauvons Calais, expulsion of illegal immigrants". Competitors such as Samuel Delcloy accuse Rêche of taking advantage of the social movement to get elected. However, things can seem more ambiguous: can we really talk about electoral opportunism? Another explanation could be that Sauvons Calais activists use of the election campaign as a platform to put forward their claims. The presence of the slogan "Sauvons Calais, expulsion of illegal immigrants" that is written bigger than the names of the candidates might hint towards that hypothesis, as thousands will see the slogan in electoral booths. Yet, we cannot be categorical about this hypothesis at this stage of our fieldwork.

\subsection{A Cloudy Relationship with Law Enforcement Agencies}

What also strikes us in our investigation is the cloudy and ambiguous relationship between the group and the authorities.

Thus the links between the group and the municipality of Calais seem quite complex. Let us first recall that the group claims to be founded to answer a call from the Mayor of Calais, with the objective of denunciating squats.

Yet, at first, city hall seems to distance itself quite strongly from Sauvons Calais. Thus, in an interview, Emmanuel Agius, deputy mayor had very harsh words concerning the collective. He told us that there is "no violence on the part of Calais people against migrants, this is not the style of the house." When we asked him about Sauvons Calais, he addeds, "These are not the people from Calais, these are just thugs, they have nothing to do with Calais." He continued by asking repeatedly "for the dissolution of Sauvons Calais, as they prompt serious disturbances of public order." He also 
assured us never "to have met in his office these thugs" who "are outside the French Republican perimeter."

We have a different story on the side of Sauvons Calais activists. Michael Paepe says he had been received by Emmanuel Agius at the end of one of the first demonstrations of the group. This information was confirmed by Samuel Delcloy, as well as by C., No Border activist, who closely follows the activities of Sauvons Calais. We can see a first ambivalence in the relationship between government and the group, the First Deputy Mayor of Calais denying having met the activists against all evidence...

The relationship between Sauvons Calais and the police and the prefecture is equally ambiguous. Indeed, although the group denies it, it is engaged in a form of political violence: vigilantism. In its political communication, group members declare themselves against any violent action. Many interviews we led contradict this affirmation: there are repeated assaults on activists and migrants, the siege of the Coulogne squat, etc. In addition, part of the group's communication is reprehensible by law as France has made hate speeches illegal, and Marie Hélène Calonne (lawyer) is preparing a complaint for inciting racial hatred against Sauvons Calais.

It is therefore appropriate to consider the relationship of the group with the police, in charge of enforcing the law. It seems that the attitude of the prefecture towards the group varies, depending on the type of activities it undertakes.

We can notice a strong answer regarding public events. After the demonstration of 7 September 2014, marked by numerous clashes, demonstrations of the group are systematically banned. This is the case of the demonstration of 25 January 2015, 7 June 2015, and November 10, 2015. On February 6, 2016, Sauvons Calais organizes a demonstration against Islam in the framework of the European Day organized by the German movement PEGIDA (European Patriots Against Islamization).It was held despite the ban of the prefecture. Twenty militants were arrested after several clashes. Among them was General Picquemal, former head of French paratroopers, who openly stateed his support for the movement. The event created a national media scandal.

Other far-right demonstrations that are not directly related to Sauvons Calais suffer the same fate. Thus, the spectacular demonstration staged by Generation Identitaire, which block the motorway with barricades painted with anti-refugee messages, is very strongly repressed: all participants are arrested and three of them sentenced to several months of prison [18]

The police have a pretty tough attitude regarding the social movement activities of Sauvons Calais, especially the demonstrations. This rather uncompromising attitude is not to be found anywhere when it comes to vigilantism.

Thus, since the group's creation, many attacks occur in its wake. We can mention the aggression of Nelle, activist of Calais Ouverture et humanité, dozens of attacks against refugees between 2014 and 2016, and an attempted kidnapping of Calais Ouverture et humanité president
Séverine Mayer. We can also count the aggression of a group of No Border activist in a bar, as Philippe Wannesson explains. For each assault complaints are filed. Yet the law enforcement agencies have failed to act. There will eventually be the arrest of a group of far-right activists posing as police in February 2016, after two years of repeated aggressions and assaults against refugees [19].

Similarly, Gaël Rougemont, member of Sauvons Calais, brandished a gun on the sidelines of a refugee demonstration on January 23, 2016, threatening to use his gun if refugees did not leave his garden. His action received national coverage. Calais district attorney decided not to uphold any charges against him even though he threatened to kill migrants with a weapon.[20].

As we mentioned above, we observed a similar attitude of security forces during the siege of the Coulogne squat. Despite daily presence of the police, no arrest was made, even though stone were thrown on the houses for eight days. Similarly, two Molotov cocktail were thrown on the house, but no arrests were made despite repeated phone calls to the police from No Border activists. Similarly, after the arson of the farm, no one was arrested.

Concerning this situation a hypothesis made by Philippe Wannesson is very interesting. The emergence of Sauvons Calais intervenes at a particular moment. Indeed, at the beginning of 2014, following a rise in legal skills by No Border activists, governments cannot evict squats anymore immediately. They have to stage several months of legal battle, sometimes almost a year. In this context, the creation of the collective is timely. Indeed, previously evictions were immediately executed without any legal procedure in what is called "immediate administrative expulsion", also nicknamed "red-handed" [21]. The actions of the No Border which have a substantial legal experience made these evictions impossible, leading to refugee squats lasting several months instead of days. In this context, according to Wannesson, Sauvons Calais would have acted as a militia. Faced with the impossibility of expelling the Coulogne squat, the police would have given a "free hand" to Sauvons Calais to do the job that the police could not legally do.

Here are some elements of analysis of the relationship between the group and the government. Speaking of straight forward outsourcing of policing to Sauvons Calais would not make sense because the police have very little tolerance for public demonstrations of the group. On the other hand, the vigilante activities are not being repressed, giving the impression of "laissez-faire" in a context where the action of the police is sometimes impossible for legal or political motives. It is for these reasons that we talk about a cloudy and complex relationship with the police and local officials.

\section{Conclusions: A Group that Matters in Calais}

In a context of exacerbated social conflict related to the special situation of Calais, Sauvons Calais is a group that 
adopts a particular strategy. Politically, it is part of the lineage of historical fascism, as its main claim is the establishment of concentration camps and the deportation of migrants. Its activity is at the confluence of a right wing social movement and a militia.

We can also note that this group is an interesting object of study because its action has an ability to mobilize parts of the Calais public. Its appeal is real, although being mostly on the Internet, with the exception of the episode of Coulogne, which leads to an intense street mobilization and is followed over a long period (a fortnight of daily demonstrations).

Similarly, its calls for the denunciation of squats but also to individual action against refugees have met some success as we have seen. On a similar note, the demonstrations gather successfully hundreds of participants, with the limit that they principally aggregate radicalized far-right militants coming from all over France, and are very often banned by the prefecture.

Despite some limitations such as very poor public image and the banning of many of its demonstration, Sauvons Calais action has met some success. It helped give visibility to vigilantism in France, but also to make Calais a focus point for a big part of the radical far right. Understanding the dynamics of this group is important because in France, in the context of the refugee crisis as well as increasing communitarian tensions, it is not impossible that such groups start multiplying on the whole French territory.

\section{REFERENCES}

[1] Abrahams, Ray, Vigilant Citizens. Vigilantism and the State (Cambridge, Polity Press, 1998).

[2] Philippe Wannesson, «Une Europe des jungles », Plein droit (Gisti, Paris, 2015/1 n 104),p. 18-21.

[3] Patrick Henriot, « Les opérations d'évacuation des jungles: le fiasco du traitement contentieux de masse », Plein droit (Gisti, Paris, 2015/1 $\mathrm{n}^{\circ}$ 104)p. 1-8.

[4] An OQTF is an obligation to leave the French territory. It allows the police to arrest migrants and to place them in a closed detention center while awaiting deportation.

[5] Jean-Pierre Alaux, «Calais vaut bien quelques requiem», Plein droit (Gisti, Paris, 2015/1 n 104), p. 3-8.

[6] «L'expulsion du bidonville de Calais commence» [En ligne:http://www.lemonde.fr/immigration-et-diversite/article/ 2016/03/01/l-evacuation-du-bidonville-de-calais-commencedans-la-violence-et-la-confusion_4874083_1654200.html] Consulté le 11/06/2016

[7] «Amin Trouvé Baghdouche, coordinateur général mission migrants à Calais pour Médecins du Monde du 30 juillet 2016», [En ligne :

https://www.franceinter.fr/emissions/l-invite-du-week-end/l-i nvite-du-week-end-30-juillet-2016]. Consulté le31 juillet
2016.

[8] «France : Les migrants et les demandeurs d'asile victimes de violence et démunis | Human Rights Watch », [En ligne : https://www.hrw.org/fr/news/2015/01/20/france-les-migrants -et-les-demandeurs-dasile-victimes-de-violence-et-demunis]. Consulté le29 juillet 2016.

[9] Mathilde Pette, «Les associations dans l'impasse humanitaire?», Plein droit (Gisti, Paris, 2015/1 n 104), p. 22-26.

[10] The National Front is the main far-right political party in France. It achieves high electoral scores.

[11] Which means «Save Calais». The subtitle of the name of the group is «From the refugees».

[12] This party is a radical right-wing splinter group of the National Front. For more details refer toNicolas Lebourg, « Chapitre 5 / Le Front National et la galaxie des extrêmes droites radicales ", in Sylvain Crépon et al., Les faux-semblants du Front national, (Presses de Sciences Po (P.F.N.S.P.) « Académique », 2015 ) p. 121-140.

[13] The Identitaire block is a radical far right movement, much more to the right than the National Front. It is characterized by a very strong Islamophobia.

[14] H. Jon Rosenbaum and Peter C. Sederberg « Vigilantism: An Analysis of Establishment Violence” Comparative Politics, (New York, Vol. 6, No. 4 Jul., 1974), pp. 541-570

[15] L'Oeuvre française is a far right organization claiming its Petainism. It was dissolved in August 2013 after the assassination of the young antifascist Clement Meric by skinheads. Despite its dissolution for its "battle group" activities, it remains very active politically under the "Jeune Nation" label.

[16] H. Jon Rosenbaum and Peter C. Sederberg « Vigilantism: An Analysis of Establishment Violence” Comparative Politics, (New York, Vol. 6, No. 4 Jul., 1974), pp. 541-570

[17] In both countries, extreme right groups have created militias in uniform that have reached a certain magnitude. They are linked to the neo-Nazi party Jobbik in Hungary and the extreme right party Lega Norde in Italy.

[18] «Calais: Trois participants à la manif de Génération identitaire ont été condamnés», [En ligne: http://www.20minutes.fr/lille/1806563-20160315-calais-trois -participants-manif-generation-identitaire-condamnes]. Consulté le28 juillet 2016.

[19] «Calais : cinq agresseurs de migrants se faisant passer pour des policiers déférés», [En ligne: http://www.liberation.fr/france/2016/03/11/calais-cinq-agress eurs-de-migrants-se-faisant-passer-pour-des-policiers-deferes _143899 4]. Consulté le28 juillet 2016.

[20] «L'homme qui avait brandi un fusil sur des migrants de Calais ne sera pas poursuivi», [En ligne:

http://www.huffingtonpost.fr/2016/03/10/fusil-calais-gael-rou gemont-droite-justice_n_9426886.html]. Consulté le28 juillet 2016.

[21] «Des No Border sans frontière», Plein Droit, (Gisti, Paris, 2015/1 n 104), p. 9-13. 